\title{
COMMENTARY
}

\section{Extrathyroidal thyroid hormone synthesis?}

\author{
Marian Ludgate \\ School of Medicine, Centre for Endocrine and Diabetes Sciences, Cardiff University, Heath Park, Cardiff CF14 4XN, UK \\ (Correspondence should be addressed to M Ludgate; Email: ludgate@cf.ac.uk)
}

\begin{abstract}
A paper published in this issue of the Journal of Endocrinology has revisited the hypothesis that thyroid hormones may be generated by tissues outside the thyroid gland in higher organisms including mammals. This commentary appraises the strengths and weaknesses of the study, the alternative explanations for the findings and possible future measures to

investigate further. The concept of extrathyroidal thyroxine and triiodothyronine synthesis has previously been proposed; by assuming that Nagao et al. and earlier authors are correct, the plausibility and possible mechanisms underlying the hypothesis are discussed.

Journal of Endocrinology (2011) 210, 3-4
\end{abstract}

In a paper entitled 'Influence of thyroidectomy on thyroxine metabolism and turnover rate in rats', Nagao et al. (2011) have investigated thyroid hormone kinetics in the hypothyroid state.

In a number of carefully performed studies, which rely on a robust online solid-phase extraction liquid chromatography mass spectrometry (MS)/MS protocol developed by the authors to measure serum thyroxine $\left(\mathrm{T}_{4}\right)$, triiodothyronine $\left(T_{3}\right)$ and reverse $T_{3}$, they demonstrate that serum levels of all three forms of iodothyronine are decreased but not completely ablated in thyroidectomised rats.

They postulate that deiodination of $T_{4}$ is enhanced by hypothyroidism to maintain levels of the biologically active thyroid hormone $\mathrm{T}_{3}$ (Kohrle 2000). This could be verified by measuring deiodinase transcripts and enzyme activity in the peripheral tissues of the thyroidectomised rodents compared with euthyroid controls.

Their second, and more controversial, conclusion is that the low levels of thyroid hormone, which persist, are due to extrathyroidal production of iodothyronines. The more mundane explanation, that fragments of thyroid tissue remain, has been excluded by histopathological examination of the trachea, although radio-iodine uptake studies would have provided more solid re-assurance.

An alternative reservoir is reported in studies that indicate a role for the gut flora in absorbing and even deiodinating thyroid hormones (Distefano et al. 1993). To exclude this interesting possible source of the persisting $T_{4}$ and $T_{3}$, experiments could be conducted in rodents in which the intestinal bacteria had been reduced by antibiotic treatment.
Assuming that the authors are correct, and that thyroid hormones are produced outside the thyroid, how could this be realised? Thyroid hormone production requires a peroxidase enzyme, a source of iodine, a system to generate $\mathrm{H}_{2} \mathrm{O}_{2}$ and a substrate containing tyrosine residues (Vassart \& Dumont 1992). In the mammalian thyroid, millennia of evolution have enabled the required components to be optimised in the form of thyroid peroxidase (TPO), the sodium iodide symporter (NIS), the dual oxidases (DUOX) and thyroglobulin (Tg), but alternatives exist.

TPO mRNA expression has been reported in extrathyroidal locations (Lai et al. 2006), but even if it is unique to the thyroid, lactoperoxidase or myeloperoxidase could provide very adequate substitutes. Iodide trapping is not restricted to the thyroid with breast, salivary gland, stomach and placenta being among the tissues in which convincing evidence for expression of a functional NIS exists (De la Vieja et al. 2000). Similarly, the dual oxidases DUOX1 and DUOX2 are widely expressed in tissues as diverse as the lung and the skin (Song et al. 2007) and even $\mathrm{Tg}$ has been detected in many regions; if iodinated, it is usually assumed to have a thyroidal origin (Lisi et al. 2002). However, if $\mathrm{Tg}$ is restricted to the thyroid might not any protein with appropriately placed tyrosine residues suffice? The Tg molecule is huge, yet the few tyrosines implicated as substrates for iodothyronine production are located at the extremities of the protein, no doubt where they can be accessed by TPO (Dunn \& Dunn 1999).

It is generally accepted that invertebrates do not have a discrete thyroid gland and yet many such species use thyroid hormones, which may be ingested, form spontaneously or be 
produced via catalysis. On the contrary, most vertebrates do possess a thyroid gland; although in the larval stages of the most primitive, thyroid hormones are produced by the endostyle (Crockford 2009); do the experiments of Nagao et al. hint at cells that could be considered to be a vestigial endostyle in higher organisms?

The notion of extrathyroidal hormone production is not new with authors from the sixties, and possibly earlier, providing solid evidence for the process (Evans et al. 1966, Taurog \& Evans 1967, Obregon et al. 1981). Most recent evidence reports that in vitro, cardiomyocytes express all of the required components and are able to produce thyroid hormone (Meischl et al. 2008).

Thyroid hormones are essential to the development and maintenance of, for example, the brain and skeletal system and for regulation of the basal metabolic rate (Boelaert \& Franklyn 2005); hence, it seems reasonable that higher organisms might have retained a back-up source. Although in vitro models can be very informative, it is hoped that Nagao et al. will extend their in vivo studies in a manner that will convince even the most sceptical thyroidologist and provide insight into the cells/tissues capable of this feat.

\section{Declaration of interest}

The authors declare that there is no conflict of interest that could be perceived as prejudicing the impartiality of the research reported.

\section{Funding}

This research did not receive any specific grant from any funding agency in the public, commercial or not-for-profit sector.

\section{References}

Boelaert K \& Franklyn JA 2005 Thyroid hormones in health and disease. Journal of Endocrinology 187 1-15. (doi:10.1677/joe.1.06131)

Crockford SJ 2009 Evolutionary roots of iodine and thyroid hormones in cell-cell signalling. Integrative and Comparative Biology 49 155-166. (doi:10. 1093/icb/icp053)
De la Vieja A, Dohan O, Levy O \& Carrasco N 2000 Molecular analysis of the sodium/iodide symporter: impact on thyroid and extrathyroid pathophysiology. Physiological Reviews 80 1083-1105.

Distefano JJ, Deluze A \& Nguyen TT 1993 Binding and degradation of $3,5,3^{\prime}$-triiodothyronine and thyroxine by rat intestinal bacteria. American Journal of Physiology 264 E966-E972.

Dunn JT \& Dunn AD 1999 The importance of thyroglobulin structure for thyroid hormone biosynthesis. Biochimie 81 505-509. (doi:10.1016/S03009084(99)80102-3)

Evans ES, Schooley RA, Evans AB, Jenkins CA \& Taurog A 1966 Biological evidence for extrathyroidal thyroxine formation. Endocrinology $\mathbf{7 8}$ 983-1001. (doi:10.1210/endo-78-5-983)

Kohrle J 2000 The deiodinase family: selenoenzymes regulating thyroid hormone bioavailability. Cellular and Molecular Life Sciences 57 1853-1863. (doi:10.1007/PL00000667)

Lai OF, Zaiden N, Goh SS, Mohamed NE, Seah LL, Fong KS, Estienne V, Carayon P, Ho SC \& Khoo DH 2006 Detection of thyroid peroxidise mRNA and protein in orbital tissue. European Journal of Endocrinology 155 213-218. (doi:10.1530/eje.1.02205)

Lisi S, Mariona M, Pinchera A, Mazzi B, di Cosmo C, Sellari-Franceshini S \& Chiovato L 2002 Thyroglobulin in orbital tissue fro patients with thyroidassociated ophthalmopathy: predominant localization in fibroadipose tissue. Thyroid 12 351-360. (doi:10.1089/105072502760043413)

Meischl C, Buermans HP, Hazes T, Zuidwijk MJ, Musters RJP, Boer C, van Lingen A, Simonides WS, Blankenstein MA, Dupuy C et al. 2008 H9c2 cardiomyoblasts produce thyroid hormone. American Journal of Physiology. Cell Physiology 294 C1227-C1233. (doi:10.1152/ajpcell.00328.2007)

Nagao H, Imazu T, Hayashi H \& Takahashi K 2011 Influence of thyroidectomy on thyroxine metabolism and turnover in rats. Journal of Endocrinology 210 117-123. (doi:10.1530/JOE-10-0484)

Obregon MJ, Mallol J, Escobar del Rey F \& Morreale de Escobar G 1981 Presence of L-thyroxine in tissues from thyroidectomised rats. Endocrinology 109 908-913. (doi:10.1210/endo-109-3-908)

Song Y, Driessens N, Costa M, DeDeker X, Detours V, Corvilain B, Maenhaut C, Miot F, Van Sande J \& Dumont JE 2007 Roles of hydrogen peroxide in thyroid physiology and disease. Journal of Clinical Endocrinology and Metabolism 92 3764-3773. (doi:10.1210/jc.2007-0660)

Taurog A \& Evans ES 1967 Extra-thyroidal thyroxine formation in completely thyroidectomised rats. Endocrinology 80 915-925. (doi:10.1210/endo80-5-915)

Vassart G \& Dumont JE 1992 The thyrotropin receptor and the regulation of thyrocyte function and growth. Endocrine Reviews 13 596-611. (doi:10. 1210/edrv-13-3-596)

Received in final form 24 February 2011

Accepted 3 May 2011

Made available online as an Accepted Preprint

3 May 2011 